\title{
How Did the Tax Cuts and Jobs Act Impact Stock Prices, Business Investment, Economic Growth and Unemployment in the United States?*
}

Submitted 17/09/21, 1st revision 05/10/21, 2nd revision 20/11/21, accepted 05/02/22

\author{
Elizabeth C. Ekmekjian ${ }^{1}$, Tricia Coxwell Snyder ${ }^{2}$
}

\begin{abstract}
:
Purpose: In this paper, we empirically examine how the Tax Cuts and Jobs Act impacted business decisions to alter investment, output, stock prices and unemployment in the U.S.

Design/Methodology/Approach: We use annual data from 1960-2019 to determine the impacts that the U.S. corporate tax rates have on business fixed investment, stock prices (measured as DJIA), output measured as real GDP, and the civilian unemployment rate.

Findings: Results show that the tax cuts generate a large increase in the stock market, but have a small and insignificant impact on GDP, business investment and unemployment.

Practical Implications: The Tax Cuts and Jobs Act of 2017, cut the maximum corporate tax rate in the United States (U.S.) from 35\% to $21 \%$ and went into effect in January 1, 2018. Supply-side economist argue that this reduction will encourage U.S. businesses to hire more workers and increase investment as they bring back production to the U.S., helping to increase business investment and output, and reduce unemployment. Keynesian economist who opposed the tax cut believe that it will have little impact on business investment, output or jobs, and be used to increase profits and stock prices as well as the Federal Deficit and Debt.
\end{abstract}

Keywords: Tax cuts, Keynesian economics, unemployment, Federal deficit and Debt.

JEL codes: E20, E24.

Paper type: Research article.

\footnotetext{
${ }^{1}$ Professor Dr., William Paterson University of New Jersey

${ }^{2}$ Professor Dr., William Paterson University of New Jersey, SnyderT@wpunj.edu;

*This article has been presented at ICABE 2021 at WPUNJ www.icabe.gr
} 


\section{Introduction}

In 2017, President Trump and Congress passed the Tax Cuts and Jobs Act that cut corporate taxes on all businesses from a maximum tax rate of $35 \%$ to $21 \%$, which went into effect January 1, 2018. Prior to 2018, the U.S. had the highest statutory corporate tax rate in the developed world. While U.S. tax rates were at a maximum of $35 \%$, other countries had lower tax rates to try to attract corporate investment. This tax differential may have caused American companies to move to low-tax jurisdictions to increase their after-tax profits.

Economist, accountants, and tax specialist have had a long standing debate over how tax policy impacts' business decisions and the overall economy. The Supply-side economic model supported by Taylor, Blanchard and Perotti, suggests that corporate tax cuts help increase business' after-tax profits, creating an incentive for businesses to invest and produce more in the U.S., as well as generate jobs. They argue that high tax rates reduce jobs and investment, leading to lower output and higher unemployment in the U.S. They advocate for a reduction of corporate taxes to spur investment, output and employment.

Keynesian economist, such as Blinder, Romer and Romer, opposed the tax cuts because they believe that corporate tax cuts will be used primarily for stock buy backs to help increase stock prices and shareholder wealth, instead of encouraging businesses to increase investment, output, and jobs. These opponents fear that the tax cuts will only increase the stock market, Federal Deficit and Debt, which in turn will increase interest rates and the borrowing cost of capital, causing a reduction in business investment and output. They advocate to cut sales and income taxes for the poor to help stimulate the demand for goods, instead of corporate tax cuts to stimulate the supply of goods.

In view of this long standing debate, we examine the effects that corporate taxes have on the U.S. economy using annual data from 1960-2019. An error correction vectorautoregression (ECM) model is used to empirically determine the impact that corporate taxes have on business investment, output, the stock market, and unemployment. Using an ECM model is a unique way to let the data speak for itself.

Results show that while tax cuts help to generate an increase in the stock market and GDP, the impact on GDP dies quickly and becomes statistically insignificant after the first year. Results also support the Keynesian model and show that corporate tax cuts appear to have little to no statistical impact on business investment and unemployment.

\section{Literature Review}

There has been a long standing theoretical debate about whether the supply or the demand for goods is the driving force in the U.S. economy. Supply side economist 
such as Taylor, Blanchard and Perotti support a corporate tax cut in the U.S. (Perotti, 2012) and (Blanchard and Perotti, 1999; 2002) show that tax cuts can have a strong positive impact on GDP. Additionally, (Chari and Kehoe, 1999) develop a set of theoretical policy rules that are largely confirmed by (Taylor, 1992; 2000) showing that tax cuts generate economic growth and reduce unemployment.

In contrast, economist such as Blinder, Romer and Romer, who support the Keynesian model, suggest that the production of goods is determined by the demand for goods, with greater consumer demand causing firms to increase production, output and employment. (Romer and Romer, 2009; 2010) suggest that a cut in corporate taxes does not increase consumer, business or government demand, which in turn will not cause an increase in business investment, GDP, wages or jobs. (Blinder, 2008) also suggests that while tax cuts may have been simulative in the 1960s, by the 1990s, after years of budget deficits, tax increases may be simulative by reducing the long-term interest rate. The body of theoretical research has not reached a consensus regarding the impacts and usefulness of corporate tax cuts.

Empirical research regarding the impacts of corporate taxes on the real economy are mixed. (Mountford and Uhlig, 2009), empirically find that tax changes have a relatively large simulative power for business investment and GDP. Similarly, (Mitchell, 2001) found that tax cuts in the 1920s, 1960s and 1980s resulted in faster economic growth in the years to follow by $4-6 \%$. Mitchell goes on to argue that future tax cuts should encourage small business growth thereby helping to stimulate the economy.

In contrast, (Poturba, 1988) and (Garrison, 1991) find that tax cuts have little impact on the components of aggregate demand and economic growth. (Cardia, 1991) empirically found that tax changes play only a minor role in changing investment and output. Romer and Romer empirically find that tax cuts create fewer jobs than direct increases in government purchases.

Using a vector autoregression approach (VAR) estimation, (Merten and Ravn, (2010; 2011a; 2011b) find that a one percentage point tax cut generates 0.4 percent increase in GDP the first year and a 0.6 percent increase in real per capita GDP after one year. However, they find that the maximum increase in employment after a one percent cut in the tax cut is only 0.3 percent and that it is statistically insignificant. Thus, Merten and Ravn conclude that tax cuts help increase GDP, but do not have a statistically significant impact on employment. In contrast, (Monacelli, Perotti, and Trigari, 2010) investigate the effects of tax shocks on unemployment and other labor market variables and find that tax cuts lead to delayed but sizeable reductions in unemployment.

Building on this literature we investigate the relative predictive power of corporate tax changes on business investment, output, stock prices and unemployment using annual data from 1960 to 2019. More specifically, we empirically estimate the 
impacts of the U.S. corporate tax rate on business fixed investment, stocks measured as the DJIA, output measured as real GDP, and the Civilian Unemployment rate using annual data collected from the St. Louis Federal Reserve FRED and Taxsim websites.

\section{Methodology}

To empirically examine the impacts of corporate tax cuts on business investment, output, stock prices and unemployment we build on the work of Merten and Ravn and Mountford and Uhlig and use an error correction vector autoregression (ECM) model with annual data from 1960-2019. As Mountford and Uhlig show, this technique is well suited to examine fiscal policy shocks, by stepping back from the long standing theoretical debate and lets the data speak for itself. Thus, to avoid imposing potentially spurious a priori constraints on the exogeneity of the variables in the system and to allow us to incorporate the proper lags of each series, this approach helps to avoid both a simultaneity and omitted variable bias. We also advance the discussion by using more recent data, from 1960 to 2019.

Since the theory underlying the estimation of any VAR technique is based upon the use of stationary data, to determine if each series is stationary we estimated the Augmented Dickey Fuller (ADF) and Phillips-Perron (PP) unit root tests and find that a unit root cannot be rejected at the conventional 5\% significance level. This suggests that each of the series has a unit root and is nonstationary, similar to that of Mountford and Uhlig, who suggest that if the series are nonstationary, then estimating a standard VAR model will be misspecified due to omitting an errorcorrection representation.

However, if each variable is nonstationary and there is a long-term (cointegration) relationship between the variables, then an error correction model (ECM) model can be employed. To determine if there is cointegration and the proper number of cointegrating terms for the ECMs, the Johansen test is estimated for each specification. To perform the Johansen test, M2 is normalized to one. Results indicate that the insertion of one cointegrating term is necessary to make the system stationary and are available upon request.

All estimations use one cointegrating equation in the ECM and this cointegrating term is a linear combination of variables in the model, which adds information regarding the long-term relationships between these variables, making the results more efficient than a standard VAR. To determine the proper lag length of each variable, this study uses the Log Likelihood Ratio, Akaike Information Criteria (AIC) and the Schwarz Information Criterion (SBC) and finds the that proper lag length is four. All preliminary tests, including the ADF, PP, Johansen, AIC and $\mathrm{SBC}$ test results are available upon request. 
Since all estimates use a Cholesky decomposition (to ensure that the covariance matrix of the innovations is diagonal), IRF results may be dramatically altered depending upon the order of equations in the system. Following Mountford and Uhlig, reported results have placed tax changes before investment, stock market, GDP and $U$ changes, since investment, output and unemployment behavior potentially responds to changes in taxes. This ordering is consistent with Taylor and the interest rate transmission mechanism ordering, yet it also incorporates the relative price and wealth effect mechanisms. While the chosen recursive model is not implied to represents the true structure of the economy, it does provide a basis to present evidence. All models are re-estimated with alternative orderings to avoid the potential sensitivity of results and are available upon request.

When using an ECM approach, it is also useful to examine the impact of a given variable on itself and on all other variables in the system by using impulse response functions (IRF) and forecast error variance decompositions (FEVD). Thus, using the more general approach of a vector autoregression allows for us to examine the effectiveness of tax policy on business investment and economic growth. In general the estimated ECM is:

$$
\Delta y_{t}=\Pi_{0}+\Pi y_{t-j}+\Pi_{1} \Delta y_{t-1}+\Pi_{2} \Delta y_{t-2}+\ldots . \Pi_{p} \Delta y_{t-p}+e_{t}
$$

where $y_{t}$ is a vector of endogenous variables (Business Fixed Investment, GDP, Unemployment, Corporate Tax rates, DJIA), $\Pi$ is a matrix with elements $\Pi_{j k}$ such that one or more of the $\Pi_{j k} \neq 0, \Pi_{i}$ is a (nxn) coefficients matrices, $t$ represents the time period, $p$ represents the lag length, and $e_{t}$ is a (nx1) vector of error terms. Economic data on real fixed business investment, real GDP, Civilian Unemployment, DJIA and after tax profits are collected from the St. Louis Federal Reserve website and tax data is collected from Line 30, Form 1120.

\section{Results}

One advantage of using an ECM is that it allows the true underlying causal relationships to express itself. A central issue in examining these effects is timing, making an investigation of forecast error variance decompositions (FEVD) and impulse response functions (IRF) useful in determining the impacts of tax policy on real variables. FEVD's are used once an ECM has been fitted to indicate the amount of information each variable contributes to the other variables in the autoregression. FEVDs determine how much of each of the variables can be explained by exogenous shocks to the other variables. Thus, FEVDs are a useful tool to compare the forecast error variance of GDP and Business investment explained by shocks to corporate taxes, stocks and unemployment and allows one to examine which innovations better explain the error variance the other variables. 
How Did the Tax Cuts and Jobs Act Impact Stock Prices, Business Investment, Economic Growth and Unemployment in the United States?

8

Results from FEVD, Tables 1-4 show that corporate tax cuts have very little impact on output and unemployment. Table 1 shows that GDP explains most of its own innovations, with unemployment and investment explaining more overtime. Unemployment explains close to ten percent of the movements in GDP. In contrast, corporate tax rates explain less than $2 \%$ of movements in GDP, suggesting that shocks to corporate tax rates have virtually no impact on the overall economy. These results support those found by Poterba, Garrsion, and Romer and Romer who found that tax cuts have little impact on GDP and economic growth.

Table 1. FEVD of GDP

\begin{tabular}{|l|l|l|l|l|l|l|}
\hline Period & S.E. & GDP & Tax Rate & Unemployment & DJIA & $\begin{array}{l}\text { Business } \\
\text { Investment }\end{array}$ \\
\hline 1 & 154.7698 & 100.0000 & 0.000000 & 0.000000 & 0.000000 & 0.000000 \\
\hline 2 & 288.4311 & 94.06807 & 0.665985 & 0.939396 & 4.100360 & 0.226185 \\
\hline 3 & 391.5688 & 90.38248 & 1.323446 & 3.897714 & 3.598435 & 0.797924 \\
\hline 4 & 480.8822 & 87.15718 & 1.282539 & 6.456106 & 3.473986 & 1.630189 \\
\hline 5 & 556.4869 & 84.14588 & 1.363582 & 8.748827 & 3.450937 & 2.290774 \\
\hline 6 & 619.9341 & 81.74349 & 1.510497 & 10.39513 & 3.421111 & 2.929769 \\
\hline 7 & 677.1071 & 80.28577 & 1.559480 & 11.55939 & 3.329773 & 3.265586 \\
\hline 8 & 730.0201 & 79.34832 & 1.583685 & 12.43484 & 3.243069 & 3.390082 \\
\hline
\end{tabular}

Source: Own study.

Table 2. FEVD of Business Investment

\begin{tabular}{|l|l|l|l|l|l|l|}
\hline Period & S.E. & GDP & Tax Rate & Unemployment & DJIA & Business Investment \\
\hline 1 & 102.9285 & 83.42087 & 1.059385 & 0.057817 & 0.608879 & 14.85305 \\
\hline 2 & 185.8236 & 75.33394 & 2.728937 & 0.383357 & 11.05178 & 10.50199 \\
\hline 3 & 243.1514 & 64.32617 & 4.474774 & 2.449576 & 9.352283 & 19.39720 \\
\hline 4 & 285.6302 & 56.25707 & 4.412936 & 3.918781 & 8.347176 & 27.06404 \\
\hline 5 & 317.2559 & 50.12714 & 4.510305 & 5.069234 & 7.828777 & 32.46454 \\
\hline 6 & 342.3390 & 45.13284 & 4.804343 & 5.506569 & 7.476402 & 37.07985 \\
\hline 7 & 362.5169 & 41.94052 & 4.944252 & 5.606761 & 7.186655 & 40.32182 \\
\hline 8 & 379.6714 & 39.84751 & 5.050589 & 5.604728 & 6.987534 & 42.50964 \\
\hline
\end{tabular}

Source: Own study.

Table 3. FEVD of Unemployment

\begin{tabular}{|l|l|l|l|l|l|l|}
\hline Period & S.E. & GDP & Tax Rate & Unemployment & DJIA & Business Investment \\
\hline 1 & 0.749436 & 64.70090 & 0.233989 & 35.06511 & 0.000000 & 0.000000 \\
\hline 2 & 1.449451 & 76.81390 & 0.090304 & 19.45174 & 2.481422 & 1.162632 \\
\hline 3 & 1.827024 & 80.00603 & 0.264511 & 15.50964 & 3.209760 & 1.010065 \\
\hline 4 & 2.090050 & 79.52731 & 0.251747 & 13.74727 & 3.699147 & 2.774528 \\
\hline 5 & 2.274173 & 77.63040 & 0.255633 & 13.28089 & 4.183337 & 4.649741 \\
\hline 6 & 2.405518 & 74.70023 & 0.302484 & 13.94115 & 4.371566 & 6.684570 \\
\hline 7 & 2.514378 & 71.80751 & 0.297121 & 15.38284 & 4.356643 & 8.155881 \\
\hline 8 & 2.611591 & 69.16974 & 0.279918 & 17.27002 & 4.288992 & 8.991327 \\
\hline
\end{tabular}

Source: Own study. 
Table 4. FEVD of DJIA

\begin{tabular}{|l|l|l|l|l|l|l|}
\hline Period & S.E. & GDP & Tax Rate & Unemployment & DJIA & Business Investment \\
\hline 1 & 1197.572 & 12.10079 & 12.83106 & 0.043415 & 75.02473 & 0.000000 \\
\hline 2 & 1870.627 & 15.05678 & 15.06029 & 0.664271 & 67.62109 & 1.597575 \\
\hline 3 & 2337.841 & 20.42279 & 12.98306 & 1.529220 & 62.48637 & 2.578559 \\
\hline 4 & 2759.780 & 22.37244 & 11.40600 & 2.708253 & 60.48257 & 3.030736 \\
\hline 5 & 3150.786 & 21.39507 & 10.93657 & 3.483069 & 60.09745 & 4.087848 \\
\hline 6 & 3497.264 & 20.37054 & 10.65986 & 3.797548 & 60.08146 & 5.090590 \\
\hline 7 & 3794.523 & 19.59450 & 10.48697 & 3.949587 & 60.23831 & 5.730635 \\
\hline 8 & 4056.392 & 18.85408 & 10.39001 & 4.027936 & 60.51097 & 6.217011 \\
\hline
\end{tabular}

Source: Own study.

Business investment results reported in Table 2 also show that shocks to corporate tax rates explain very little of the fluctuations in Business Investment. FEVD results show that corporate tax rates explain nor more than $5 \%$ of the fluctuations in investment, suggesting that changes in corporate tax rates have very little impact on a business' decisions to invest in the U.S. In contrast, business investment appears to display "animal spirts" that show that future business investment depends on previous investment decisions and shocks to GDP, suggesting that cutting the corporate tax rate will have little impact on businesses decision to reinvest in the U.S.

Unemployment results in Table 3, show that tax changes explain less than $1 \%$ of the changes in unemployment. Results support those found by Merten and Ravn and suggest that corporate tax cuts have little impact on the unemployment rate. Similarly, business investment in the U.S. also explains very little of the changes in unemployment. This surprising finding may suggest that U.S. business investment is altering the mix of capital to labor and as businesses increase investment they are using machines in lieu of labor. As expected, unemployment appears to depend heavily on itself and GDP.

Tax cuts do have a strong impact on the fluctuations in the stock market. FEVD results in Table 4 show that shocks to corporate taxes explain between 10 to 15 percent of the fluctuations in the DJIA, suggesting that instead of using the tax savings to increase production and output and hire more workers, corporations are instead passing the savings on to the shareholders in the form of higher profits and stock prices.

Collectively, results contrast that of Monacelli, Perotti and Trigari and show that corporate tax cuts have little impact on economic growth, business investment decisions or unemployment. This supports the Keynesian model, suggesting that aggregate demand, not aggregate supply (or Tickle down Theory) is the driving force for Business Investment, GDP, and unemployment. 
How Did the Tax Cuts and Jobs Act Impact Stock Prices, Business Investment, Economic Growth and Unemployment in the United States?

10

FEVD results in Tables 5-8, that after tax profits in place of corporate tax cuts, tell a similar story, especially with regard their impact on output and unemployment. Tables 5 and 7 show that after tax profits explain close to $4 \%$ of the innovations in output and unemployment. However, FEVD results in Tables 6 and 8 show that after tax profits explain close to $12 \%$ of the innovations in business investment and close to $24 \%$ of the innovations in the stock market as the time horizon expands. This suggest that while after tax profits do not have a strong direct impact on output and unemployment, it may indirectly impact the stock market and in turn that may then impact business investment, output and unemployment.

Table 5. FEVD of GDP

\begin{tabular}{|l|l|l|l|l|l|l|}
\hline Period & S.E. & GDP & $\begin{array}{l}\text { After Tax } \\
\text { Profits }\end{array}$ & Unemployment & DJIA & $\begin{array}{l}\text { Business } \\
\text { Investment }\end{array}$ \\
\hline 1 & 136.1281 & 100.0000 & 0.000000 & 0.000000 & 0.000000 & 0.000000 \\
\hline 2 & 248.5623 & 89.50542 & 3.386021 & 1.000500 & 4.252957 & 1.855104 \\
\hline 3 & 320.5441 & 84.73691 & 3.739072 & 4.284676 & 6.087524 & 1.151822 \\
\hline 4 & 391.3799 & 76.56843 & 3.608852 & 7.850683 & 10.95544 & 1.016590 \\
\hline 5 & 471.2412 & 63.60402 & 3.324221 & 11.05919 & 20.74959 & 1.262986 \\
\hline 6 & 566.2026 & 51.84539 & 2.839908 & 12.60326 & 31.23949 & 1.471948 \\
\hline 7 & 679.9981 & 43.99542 & 2.374895 & 12.43259 & 39.49319 & 1.703907 \\
\hline 8 & 804.9618 & 40.19138 & 2.052501 & 11.67371 & 44.32726 & 1.755148 \\
\hline
\end{tabular}

Source: Own study.

Table 6. FEVD of Business Investment

\begin{tabular}{|l|l|l|l|l|l|l|}
\hline Period & S.E. & GDP & $\begin{array}{l}\text { After Tax } \\
\text { Profits }\end{array}$ & Unemployment & DJIA & Business Investment \\
\hline 1 & 79.76354 & 79.82508 & 0.418420 & 0.115825 & 0.206357 & 19.43431 \\
\hline 2 & 137.0787 & 67.70725 & 11.45306 & 0.403218 & 11.84251 & 8.593956 \\
\hline 3 & 166.8483 & 53.76057 & 12.74423 & 3.232127 & 16.60150 & 13.66157 \\
\hline 4 & 195.8564 & 40.63219 & 11.79005 & 6.270762 & 27.79915 & 13.50785 \\
\hline 5 & 242.7401 & 26.45231 & 9.377207 & 7.880621 & 46.56418 & 9.725681 \\
\hline 6 & 300.8361 & 17.22217 & 7.065719 & 7.652830 & 61.32263 & 6.736647 \\
\hline 7 & 363.5541 & 12.47844 & 5.531560 & 6.587173 & 70.68321 & 4.719617 \\
\hline 8 & 425.8551 & 11.44035 & 4.667230 & 5.636190 & 74.72279 & 3.533436 \\
\hline
\end{tabular}

Source: Own study.

Table 7. FEVD of Unemployment

\begin{tabular}{|l|l|l|l|l|l|l|}
\hline Period & S.E. & GDP & $\begin{array}{l}\text { After Tax } \\
\text { Profits }\end{array}$ & Unemployment & DJIA & $\begin{array}{l}\text { Business } \\
\text { Investment }\end{array}$ \\
\hline 1 & 0.690491 & 59.86045 & 0.017956 & 40.12160 & 0.000000 & 0.000000 \\
\hline 2 & 1.321630 & 68.83033 & 1.419695 & 23.89032 & 2.120429 & 3.739226 \\
\hline 3 & 1.603123 & 67.72795 & 2.944027 & 22.35978 & 3.970852 & 2.997384 \\
\hline 4 & 1.789147 & 63.53765 & 3.701003 & 21.88467 & 8.268036 & 2.608637 \\
\hline 5 & 1.974045 & 55.32684 & 4.075767 & 20.50562 & 17.35028 & 2.741484 \\
\hline 6 & 2.214082 & 45.25585 & 3.860050 & 18.29796 & 29.63565 & 2.950496 \\
\hline 7 & 2.519788 & 36.81184 & 3.425848 & 16.04117 & 40.53122 & 3.189921 \\
\hline 8 & 2.866024 & 31.83662 & 3.063220 & 14.24919 & 47.59316 & 3.257809 \\
\hline
\end{tabular}

Source: Own study. 
Table 8. FEVD of DJIA

\begin{tabular}{|l|l|l|l|l|l|l|}
\hline Period & S.E. & GDP & $\begin{array}{l}\text { After Tax } \\
\text { Profits }\end{array}$ & Unemployment & DJIA & Business Investment \\
\hline 1 & 1151.464 & 5.557093 & 19.72717 & 0.094375 & 74.62136 & 0.000000 \\
\hline 2 & 1768.451 & 5.642816 & 24.38301 & 0.798173 & 68.32145 & 0.854553 \\
\hline 3 & 2190.484 & 7.498997 & 21.85591 & 1.348654 & 68.15460 & 1.141834 \\
\hline 4 & 2645.702 & 7.924938 & 19.09121 & 2.468106 & 69.68759 & 0.828159 \\
\hline 5 & 3237.929 & 5.947835 & 16.13986 & 3.343880 & 74.00641 & 0.562014 \\
\hline 6 & 3861.147 & 4.690308 & 13.67088 & 3.802681 & 77.43186 & 0.404269 \\
\hline 7 & 4520.138 & 4.358892 & 11.66636 & 3.803473 & 79.87168 & 0.299594 \\
\hline 8 & 5176.879 & 4.789478 & 10.25441 & 3.718769 & 81.00563 & 0.231711 \\
\hline
\end{tabular}

Source: Own study.

Impulse Response Functions (IRF) in Figures 1-8 below, show the direction of the effect of corporate tax changes on GDP, Unemployment, Business Investment and the stock market. An IRF diagram traces the directional pattern of response over time from a one standard deviation shock in a specific variable. IRFs give useful information enabling policy makers to empirically evaluate the magnitude and sign of the impacts of shocks to corporate taxes and their ability to predict changes in BFI, GDP, DJIA, and U.

Figure 1: IRF of GDP to Corporate Tax Rates

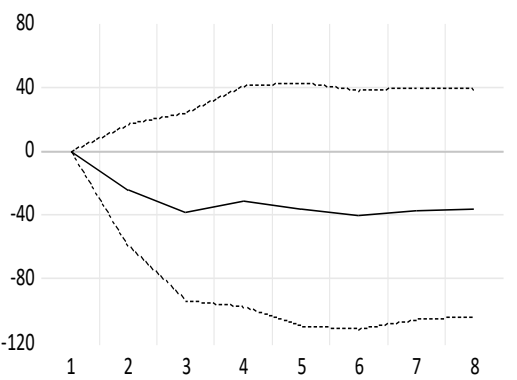

Figure 3: IRF of Unemployment Rate to Corporate Tax Rates

.6

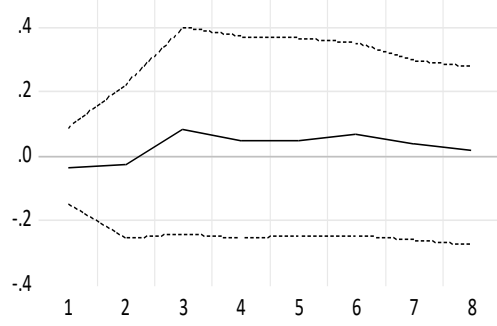

Figure 2: IRF of Business Investment to Corporate Tax Rates

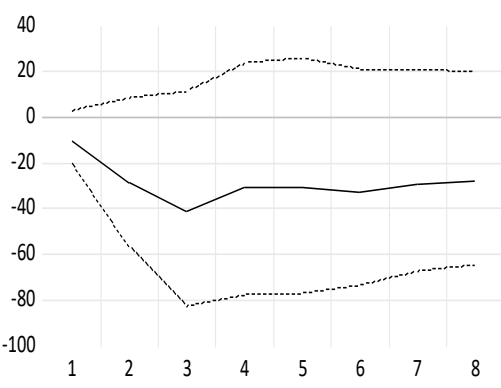

Figure 4: IRF of DJIA to Corporate Tax Rates

400

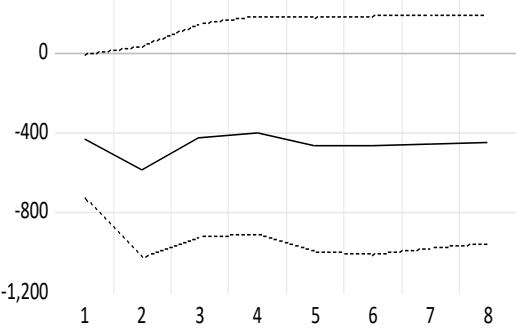



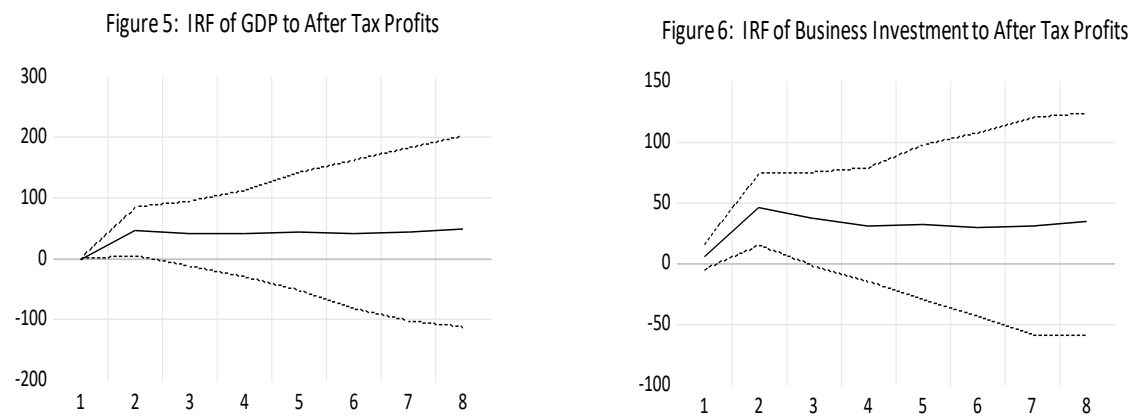

Figure 7: IRF of Unemployment to After Tax Profits

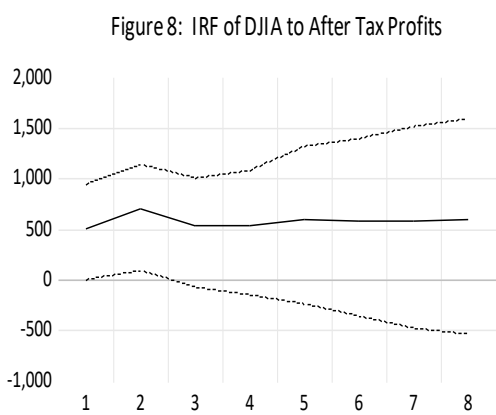

Impulse response function (IRF) results in Figures 1-4 show that while increases in corporate taxes have the expected negative impact on GDP and business investment, that the impact is extremely small and is statistically insignificant. Figures 1 and 2 show that tax cuts cause a small reduction in GDP and business investment. Unexpectedly, increases in corporate tax rates actually cause the unemployment to fall for the first few years, but this is very small and insignificant.

Results support those of Merten and Ravn and Romer and Romer and show that corporate tax rates have very little impact on the real economy. It should be mentioned, that while tax changes do not appear to impact real economic variables such as GDP and unemployment, they do continue to have a strong impact on the stock market. The IRF results in Figure 4 shows that tax cuts will increase the DJIA. Results are similar when using alternative measures of the stock market and are available upon request. It appears that corporate tax cuts may have an indirect impact on real variables through its impact on the stock market.

Results replacing the maximum tax rate with after tax corporate profits can be seen in Figures 5-8 continue to tell a similar story. IRF results show that while an increase in after tax profits increases GDP, and investment during the first few years, its impact quickly fades away and becomes insignificant. 


\section{Conclusions and Policy Recommendations}

Our results find that corporate taxes have very little impact on output, business investment and unemployment. These results support the theoretical Keynesian arguments made by Blinder and Romer and Romer. Regardless of whether corporate taxes or after tax profits are employed, results consistently show that changes in corporate tax rates have very little impact on a business' decision to hire more works, to reinvest in the U.S or to increase economic output. Results do show that while tax cuts do not impact real variables like business investment, GDP and Unemployment, they do impact the stock market. Our results do not support the Supply-side model or Trickle-down theory argued by Taylor and Blanchard and Perotti. Instead they support the Keynesian model that suggests that tax cuts will not be used to increase business investment, output and reduce unemployment, but instead be used to increase profits and stock prices.

In future studies, we hope to build on our data and results and compare the impact of corporate taxes in the U.S. and other developed countries. Second, we hope to compare the impacts of a corporate tax cut to other tax cuts, such as income tax cuts and capital gains tax cuts to see which type of tax cut has the greatest impact on economic growth, unemployment and wages. Lastly, we would like to include how tax cuts impact the deficit and debt and how that might have feedback effects on economic growth, unemployment and wages. Such applications could be very helpful in bringing about further evidence regarding the impact of tax policy on the overall economy.

\section{References:}

Blanchard, O., Perotti, R. 2002. An Empirical Characterization of the Dynamic Effects of Changes in Government Spending and Taxes on Output. Quarterly Journal of Economics, 117(4), 1329-1368.

Blinder, A. 2008. Keynesian Economics. In: D. Henderson (ed.), The Concise Encyclopedia of Economics. The Liberty Fund, 316-319.

Cardia, E. 1991. The Dynamics of a Small Open Economy in Response to Monetary, Fiscal and Productivity Shocks. Journal of Monetary Economics, 28, 411-434.

Chari, V., Kehoe, J.P. 1999. Optimal Fiscal and Monetary Policy. Handbook of Macroeconomics, J.B. Taylor, Woodford, M., (ed.), ed. 1, v.1, ch. 26, 1671-1745, Elsevier.

Garrison, C. 1991. The Role of Business Investment, Residential Investment, and Tax Incentives in the Economic Expansion of the 1980's. American Economic Journal, 19(4), 11-18.

Mertens, K., Ravn, O.M. 2010. Measuring the Impact of Fiscal Policy in the Face of Anticipation: a Structural VAR Approach. Economic Journal, 120(544), 393-413.

Mertens, K., Ravn, O.M. 2011a. Understanding the Aggregate Effects of Anticipated and Unanticipated Tax Policy Shocks. Review of Economic Dynamics, 14(1), 27-54.

Mertens, K., Ravn, O.M. 2011b. A Reconciliation of SVAR and Narrative Estimates of Tax Multipliers, manuscript. Cornell University and University College London.

Mitchell, W.F., Mosler, W. 2012. Unemployment and fiscal policy. Rutgers Journal of Law 
How Did the Tax Cuts and Jobs Act Impact Stock Prices, Business Investment, Economic Growth and Unemployment in the United States?

14

and Urban Policy, 2, 1-27.

Monacelli, T., Perotti, R., Trigari, A. 2011. Taxes and the Labor Market. Series on Central Banking, Analysis, and Economic Performance. Central Bank of Chile.

Mountford, A., Uhlig, H. 2009. What Are the Effects of Fiscal Policy Shocks? Journal of Applied Econometrics, 24(6), 960-992.

Perotti, R. 2012. The Effects of Tax Shocks on Output: Not So Large, But Not Small Either. American Economic Journal: Economic Policy, 4(2), 214-237

Poterba, J. 1988. Are Consumers Forward Looking? Evidence From Fiscal Experiments. American Economic Review, 78(2), 413-418.

Romer, C., Romer, D. 2009a. A Narrative Analysis of Postwar Tax Changes, manuscript. University of California, Berkeley.

Romer, C., Romer, D. 2009b. Do Tax Cuts Starve the Beast? The Effect of Tax Changes on Government spending. Brookings Papers on Economic Activity, 40(1), 139-214.

Romer, C., Romer, D. 2010. The Macroeconomic Effects of Tax Changes: Estimates Based on a New Measure of Fiscal Shocks. American Economic Review, 100(3), 763-801.

Taylor, J. 1993. Discretion versus policy rules in practice. Carnegie-Rochester Conference Series on Public Policy, 39, December, 196-214.

Taylor, J. 2000. Reassessing Discretionary Fiscal Policy. Journal of Economic Perspectives, 14(3), Summer, 21-36. 